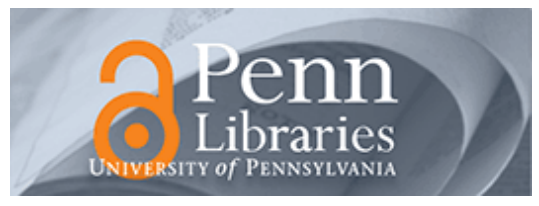

University of Pennsylvania

ScholarlyCommons

Management Papers

Wharton Faculty Research

2011

\title{
Naïveté and Cynicism in Negotiations and Other Competitive \\ Contexts
}

Chia-Jung Tsay

University of Pennsylvania

Lisa L. Shu

Max H. Bazerman

Follow this and additional works at: https://repository.upenn.edu/mgmt_papers

Part of the Business Administration, Management, and Operations Commons

\section{Recommended Citation}

Tsay, C., Shu, L. L., \& Bazerman, M. H. (2011). Naïveté and Cynicism in Negotiations and Other Competitive Contexts. The Academy of Management Annals, 5(1), 495-518. http://dx.doi.org/10.1080/ 19416520.2011 .587283

This paper is posted at ScholarlyCommons. https://repository.upenn.edu/mgmt_papers/60

For more information, please contact repository@pobox.upenn.edu. 


\title{
Naïveté and Cynicism in Negotiations and Other Competitive Contexts
}

\author{
Abstract \\ A wealth of literature documents how the common failure to think about the self-interests of others \\ contributes to suboptimal outcomes. Yet sometimes, an excess of cynicism appears to lead us to over- \\ think the actions of others and make negative attributions about their motivations without sufficient \\ cause. In the process, we may miss opportunities that greater trust might capture. We review the research \\ on when people expect too little or too much self-interest in the intentions of others, as contrasted with \\ rational behavior. We also discuss the antecedents and consequences of these naïve and cynical errors, \\ as well as some potential strategies to buffer against their effects and achieve better outcomes in \\ competitive contexts. \\ Disciplines \\ Business Administration, Management, and Operations
}




\title{
NAIVETÉ AND CYNICISM IN NEGOTIATIONS AND OTHER COMPETITIVE CONTEXTS
}

\author{
CHIA-JUNG TSAY \\ LISA L. SHU \\ MAX H. BAZERMAN
}

\author{
Harvard Business School \\ Negotiation, Organizations, and Markets Unit \\ Boston, MA 02163 \\ e-mail:mbazerman@hbs.edu
}




\begin{abstract}
A wealth of literature documents how the common failure to think about the self-interests of others contributes to suboptimal outcomes. Yet sometimes, an excess of cynicism appears to lead us to over-think the actions of others and make negative attributions about their motivations without sufficient cause. In the process, we may miss opportunities that greater trust might capture. We review the research on when people expect too little and or too much self-interest in the intentions of others, as contrasted with rational behavior. We also discuss the antecedents and consequences of these naïve and cynical errors, as well as some potential strategies to buffer against their effects and achieve better outcomes in competitive contexts.
\end{abstract}


You have just arrived at the airport in Manchester, England with three traveling companions and are looking for a taxi to take you to the local train station. You already have tickets for the train ride to London, which is 200 miles away. You approach the taxi stand, where a group of drivers are sitting around chatting. Business seems slow, and the drivers appear to know each other quite well. You request the short ride to the train station. One of drivers tells you that the trains are on strike and offers to drive the four of you to London for 300 pounds. Do you accept?

Notice that this offer leaves you vulnerable to making at least one of two obvious possible mistakes. First, you could accept the offer and later find out that the strike claim was fraudulent. This will likely make you feel quite cheated. On the other hand, you could reject the offer and seek additional information elsewhere. If the claim was truthful, however, it might be a bit awkward for you to return to the taxi stand and repeat your request for a ride. Are you the type of person who is more likely to be taken for a ride due to naiveté, or someone who is more likely to create an awkward situation due to your cynicism? In other words, are you more likely to trust too much or too little?

In fact, one of the authors of this paper was the focal actor in this story. As one of the group members was about to accept the offer of a ride to London, the author said to another member of the group, "Don't let him load the luggage yet." The author ran into the airport, up to the information booth, and quickly asked whether there was a train strike. Running back to the taxi stand, he pulled his three friends aside with the news that there was no strike: the driver's claim was a scam. Cynicism carried the day.

Trust, on the other hand, played an instrumental role in another one of the author's travels. Through the non-profit online social network CouchSurfing.org, she was able to connect 
with travelers and stay with local hosts in twenty-eight countries, who welcomed her to their homes upon meeting her for the first time. Not only did the hosts provide her with couches to sleep on, but many prepared home-cooked meals for her, accompanied her on day-long tours of their cities, and yes, even picked her up from the airport - all at no cost to the author. The more cynical among us might probe to understand why people would behave so generously toward a stranger, but consider that more than two million people worldwide have found hosts through CouchSurfing.org. Given an ample dose of trust from both guests and hosts, the network creates value by connecting travelers with otherwise empty couches and fostering authentic cultural exchanges and experiences.

This paper is about the decision errors we make in competitive contexts when we are naïve, as well as those we make when we are too cynical—which, we will argue, are opposite sides of the same problem. People often face a choice between trusting the other party and being cynical of their motives (Kramer \& Lewicki, 2010). But the "naïve versus cynical" distinction is broader than issues involving trust or personality. Here, we outline a more specific definition of naiveté, and one that departs from the common lay understanding of the concept as being simple, unsophisticated, unsuspecting, or unwary. After all, people can be naïve without invoking the issue of intelligence, and most of us have been guilty of both being too naïve and too cynical in different contexts. We describe naïve behavior as a failure to act optimally due to a lack of consideration of the strategic and self-interested perspectives of others. For example, in negotiation, we may fail to take into account the rules of the particular interaction or other parties' knowledge or motivations. In contrast, we describe someone as being too cynical when their suspicions hamper their own expected welfare. Often, these suspicions are warranted, and in fact may protect against the kinds of naïve errors discussed above. As the literature has largely 
focused on errors of naiveté rather than errors of cynicism, we shift our attention to the latter: when being cynical results in costs rather than benefits. Of course, it is often difficult to know when one is being naïve or too cynical, but experiments can help identify the triggers of each type of mistake. This paper offers a review of the evidence of these dysfunctional patterns and then explores strategies for managing them.

\section{NAÏVE ERRORS}

Much more research has focused on naïve behavior rather than cynical behavior. As such, here we only present a brief overview of some of the most illustrative examples of naïve errors, before exploring cynical errors in much greater detail. First presented by Samuelson and Bazerman (1985), the "Acquiring a Company" problem is as follows:

In the following exercise, you will represent Company A (the acquirer), which is currently considering acquiring Company $\mathrm{T}$ (the target) by means of a tender offer. You plan to tender in cash for 100 percent of Company T's shares but are unsure how high a price to offer. The main complication is this: the value of Company $\mathrm{T}$ depends directly on the outcome of a major oil exploration project it is currently undertaking. Indeed, the very viability of Company $\mathrm{T}$ depends on the exploration outcome. If the project fails, the company under current management will be worth nothing - $\$ 0 /$ share. But if the project succeeds, the value of the company under current management could be as high as $\$ 100 /$ share. All share values between $\$ 0$ and $\$ 100$ are considered equally likely. By all estimates, the company will be worth considerably more in the hands of Company A than under current management. In fact, whatever the ultimate value under current management, the company will be worth fifty percent more under the management of $A$ than under 
Company $T$. If the project fails, the company is worth $\$ 0 /$ share under either management. If the exploration project generates a $\$ 50 /$ share value under current management, the value under Company A is $\$ 75 /$ share. Similarly, a $\$ 100 /$ share value under Company T implies a \$150/share value under Company A, and so on.

The board of directors of Company A has asked you to determine the price they should offer for Company T's shares. This offer must be made now, before the outcome of the drilling project is known. From all indications, Company T would be happy to be acquired by Company A, provided it is at a profitable price. Moreover, Company T wishes to avoid, at all cost, the potential of a takeover bid by any other firm. You expect Company $\mathrm{T}$ to delay a decision on your bid until the results of the project are in, then accept or reject your offer before the news of the drilling results reaches the press. Thus, you (Company A) will not know the results of the exploration project when submitting your price offer, but Company $T$ will know the results when deciding whether or not to accept your offer. In addition, Company $T$ is expected to accept any offer by Company $A$ that is greater than the (per share) value of the company under current management.

As the representative of Company A, you are deliberating over price offers in the range of $\$ 0 /$ share (this is tantamount to making no offer at all) to $\$ 150 /$ share. What price offer per share would you tender for Company T's stock?

My Tender Price is $\$ \_$per share.

The essential features of the "Acquiring a Company" problem are that a) the acquirer is uncertain about the ultimate value of the target firm, knowing only that its value under current management is between $\$ 0$ and $\$ 100$, with all values equally likely; b) the firm is expected to be 
worth 50 percent more under the acquirer's management than under the current ownership; and c) only the target will know its true value when accepting or rejecting the offer. What is the most rational offer?

Most people respond naïvely (in the sense defined above) when answering this question, and not because of a lack of trust. The arithmetic needed to solve the problem is simple, yet naïve thinking gets it wrong. The dominant response of 123 MBA students from Boston University in the early 1980 s was between $\$ 50$ and $\$ 75$, and is naïvely consistent with the fact that, on average, the firm will be worth $\$ 50$ to the target and $\$ 75$ to the acquirer. Why is this thinking naïve? Because the other side does not randomly accept any offer presented; rather, they accept an offer selectively. They will more likely accept offers that are greater than the current value of the company. This can be seen by a more rational assessment of an offer of $\$ 60$ per share (Samuelson \& Bazerman, 1985):

If I offer $\$ 60$ per share, the offer will be accepted 60 percent of the time-whenever the firm is worth between $\$ 0$ and $\$ 60$ to the target. Since all values are equally likely, between $\$ 0$ and $\$ 60$, the firm will, on average, be worth $\$ 30$ per share to the acquirer, resulting in a loss of $\$ 15$ per share ( $\$ 45$ to $\$ 60)$. Consequently, a $\$ 60$ per share offer is unwise.

This logic applies to any positive offer. On average, the acquirer obtains a company worth 25 percent less than its offer when that offer is accepted. In other words, when the acquirer offers $\$ X$ and the target accepts, the value to the target is worth anywhere between $\$ 0$ and $\$ X$. Any value in that range is equally likely, and the expected value of the offer is therefore equal to $\$ X / 2$. With the 50 percent premium to the acquirer, the acquirer's expected value is $1.5(\$ X / 2)=0.75(\$ X)$, or 75 percent of its offer price. 
Thus, the optimal offer is $\$ 0$, or a decision to make no offer at all. Paradoxically, even though in all circumstances the firm is worth more to the acquirer than to the target, any offer above $\$ 0$ leads to a negative expected return to the acquirer, twice the chance of losing money as gaining money, and a maximum potential loss that is twice as large as the maximum potential gain. "The source of this paradox lies in the high likelihood that the target will accept the acquirer's offer when the firm is least valuable to the acquirer - that is, when it is a 'lemon' (Akerlof, 1970)," note Samuelson and Bazerman (1985).

Replications with MBA students and executive students at the Sloan School at Massachusetts Institute of Technology, the Kellogg School at Northwestern, and the Harvard Business School have produced similar results. CEOs, investment bankers, and audit partners fared little better (Bazerman \& Moore, 2008). Even when subjects were paid according to their performance and played multiple trials with feedback on their offers, the same pattern of errors persists (Ball, Bazerman, \& Carroll, 1991; Grosskopf, Bereby-Meyer, \& Bazerman, 2007; BerebyMeyer \& Grosskopf, 2008).

Most MBA students and professors can easily follow the logic that the optimal offer is $\$ 0$ per share, yet most make a positive offer when given the problem. This naïve behavior reflects the systematic exclusion of the conditional acceptance by the other party. That is, we fail to think through the future decisions of other parties. In addition, we tend to over-rely on the outcomes of previous rounds of financial investment decisions (Bereby-Meyer \& Grosskopf, 2008) and assume that others have the same limited information that we do (Carroll, Bazerman, \& Maury, 1988).

Many other examples of naïve decision-making behavior abound and have been welldocumented in competitive realms ranging from negotiations to economic games to auctions. At a more fundamental level, the focusing bias causes us to attend only to specific items or events 
(Schkade \& Kahneman, 1998; Wilson et al., 2000) or what is explicitly represented in our mental models (Legrenzi, Girotto, \& Johnson-Laird, 1993). We excluded important information from our decisions, including others' choices and the consequences of those choices, and fail to adjust our behavior accordingly (Grosskopf, Bereby-Meyer, \& Bazerman, 2007).

In one set of studies, by failing to consider how the rules of a negotiation affected others in addition to themselves, negotiators passed on options that would have resulted in strategic benefits (Moore, 2004). Even experienced negotiators expected that revealing their own deadlines would lead to worse outcomes and chose not to do so; however, such revelations actually speed up concessions from the other side and contribute to better outcomes for the negotiators. Moore highlights the "dual myopia" in how we focus on the situation's effect on ourselves and neglect consideration of how the same situation would similarly affect others. Our insensitivity to others' cognitions and decisions may result in suboptimal performance in competitive settings as a result of focusing too narrowly on problems and overweighting one's own perspective (Babcock \& Loewenstein, 1997; Bazerman \& Chugh, 2006; Idson, Chugh, Bereby-Meyer, Moran, Grosskopf, \& Bazerman, 2004; Thompson \& Loewenstein, 1992).

Naïve errors may also occur when we err by trusting others who have self-serving motives (Berg, Dickhaut, \& McCabe, 1995). In the example of the Monty Hall Problem (derived from the TV game show “Let's Make a Deal”), host Monty Hall would ask a contestant to pick one of three doors, one of which hid a prize; next, he would usually open a door that did not hold the prize. The contestant then had the option of switching from her chosen door to the remaining unopened door. Should the contestant switch doors? If the host can be trusted, mathematically, the best strategy to increase the odds of winning is to switch doors. However, when Monty has the options of declaring the game over or opening one door and offering a switch, if the host should not be 
trusted - that is, Monty knows where the prize is and does not want the contestant to win it, the contestant should not switch doors because Monty would only offer a switch if the contestant had already picked the winning door (Tor \& Bazerman, 2003).

The Monty Hall problem is an example of the "winner's curse" phenomenon ("if you won it, you probably overpaid") of competitive bidding, a problem robust across auction form, market size, and subject population (Dyer, Kagel, \& Levin, 1989). The winner's curse is created when one side has much better information than the other side about the situation (Thaler, 1988). In this section on naïve errors, we briefly surveyed several well-replicated instances of naïve errors, such as failing to account for the cognitions, decisions, knowledge, and motivations of other parties. We are all familiar with the expression "buyer beware," but our intuition has difficulty putting this idea into practice, and we ignore the hazards of making decisions based on asymmetric information. We naïvely ignore the need the importance of getting accurate information about important transactions. We undervalue a mechanic's unbiased evaluation of a used car, a professional inspector's assessment of a house, or an independent jeweler's assessment of a coveted gem.

\section{CYNICAL ERRORS}

In certain situations, we are good at avoiding the naïve mistakes described above, as in the case of the author who was appropriately skeptical of the Manchester taxi driver's claim about a train strike. But we can also fall prey to the opposite error-being inappropriately cynical and distrustful. This can arise from the lay intuition that others must be self-interested, which may be amplified through egocentric reasoning, uncertainty, and differences in our construals of the same information—conditions that are particularly relevant for negotiations and competitive contexts. And, even with the work that has shown the many benefits of training in 
negotiations, for example, we will also discuss instances in which ordinary cynicism may be further solidified by training in those fields which hold self-interest as a core basic assumption about human nature. Errors that stem from such cynicism have been neglected in the decisionmaking literature (Liu \& Wang, 2010), relative to the abundant attention given to naïve errors. In this section, we examine the suboptimal outcomes that result from being too cynical, focus on some of the relevant new research about cynical errors in negotiations and competitive contexts, and explore future directions in this literature.

\section{When Cynicism Harms Outcomes}

People may tend to be more wary of the risks of being too naïve, yet research has begun to document the ways in which we may be cynical of others' motivations and reasoning, both in interpersonal interactions and in the context of organizations. In the context of management, cynicism has been defined and treated in many different ways. Work on individual differences has considered cynicism as a personality disposition or trait (Graham, 1993; Pope et al., 1993). For example, the results of studies of the behavior of monozygotic (identical) and dizygotic (fraternal) twins in trust games have suggested that trusting behavior and reciprocal trustworthiness are in part heritable, independent of the environment in which we are raised (Cesarini et al., 2008). Our genetic endowment and the environment in which we learned to trust or distrust determine our dispositional levels of trust and cynicism.

In an interesting demonstration of the surprising impact of our immediate environment on trust, Frank, Gilovich, and Regan (1993) considered whether self-interested economists with rational mindsets were indoctrinated to be self-interested through their study of economics, or whether people who were self-interested to begin become particularly attracted to the discipline. The authors offer evidence that mere exposure to the self-interested neoclassical economics model 
encourages more self-interested, cynical behavior in both economists and non-economists alike. Furthermore, Wang, Malhotra and Murnighan found that studying economics changes people's view towards greed such that the attribute is viewed as more potentially beneficial and favorable (2010). These demonstrations that attitudes toward self-interest and greed are both malleable highlight the potential impact of incidental situational cues on turning trust into cynicism.

Other work on cynicism relates to beliefs about the social world, such as those regarding interactions between individuals or within groups and organizations (Andersson, 1996; Dean, Brandes, \& Dharwadkar, 1998; O’Connell, Holzman, \& Armandi, 1986; Reichers, Wanous, \& Austin, 1997). It may be less than surprising to learn that consumers are aware and suspicious of the persuasion and influence strategies used by marketers and advertisers (Freistad \& Wright, 1994), that the public has a growing distrust and cynicism toward public leaders and institutions (Cappella \& Jamieson, 1997), and that employees are frequently disillusioned by and distrusting of business organizations, executives, and others in the workplace (Mirvis \& Kanter, 1989), in what is termed "employee cynicism" (Andersson, 1996) or "organizational cynicism" (Wanous, Reichers, \& Austin, 1997). There has been some literature describing the corrosive effects of cynical perceptions of the workplace, ranging from individual expediency and inauthentic behavior, to the disparagement and denigration of management and organizational missions (Mirvis \& Kanter, $1989 ; 1991)$.

Here, we focus on how cynicism is characterized by negative views of human nature (Leung, Tong, \& Ho, 2004) and the dysfunctional distrust of others' intentions and motives (Deutsch, 1960; Mayer, Davis, \& Schoorman, 1995). As an example, consider this "hidden card game" between a seller and a buyer (Rubinstein, 2009; Ert, Creary, \& Bazerman, 2011): 
A deck of 100 cards includes all values between $\$ 1$ to $\$ 100$, in dollar increments. The seller starts by randomly drawing two cards from the deck. After being told the value of the lower of the two cards, the buyer must decide whether to buy the two cards from the seller at a fixed cost of $\$ 100$. The cards' value to the buyer is the sum of the two cards. The seller is rewarded a fixed amount $(\$ 10)$ if the buyer buys the cards. Thus, the seller's interest is to sell the cards regardless of their value. The buyer, on the other hand, only wants to buy the cards when they are valuable (when the sum of cards exceeds $\$ 100$ ).

Simple analysis demonstrates that a risk-neutral buyer should buy the cards whenever the value of the lower card exceeds $\$ 33$, since at $\$ 34$, all values for the other card between $\$ 35$ and $\$ 100$ are equally likely, making the sum of the two cards anywhere between $\$ 69$ and $\$ 134$, for an expected value of $\$ 101.5$ (just slightly above $\$ 100$ ), again, all values being equally likely. Ert, Creary, and Bazerman (2011) examined how buyers react when they see that the lower card is worth $\$ 40$, making all values for the combination of the two cards between $\$ 81$ and $\$ 140$ equally likely, for an expected value of $\$ 110.50$. Without the opportunity to obtain any additional information, we argue that it is rational for the risk-neutral buyer to buy the cards.

Ert, Creary, and Bazerman (2011) looked at buyer behavior in two different conditions. In one condition, the seller was an automated computer, and the potential buyer had no opportunity for communication. In a second condition, the seller was another human being, and the two parties had the opportunity to interact via e-mail. While most buyers (78\%) accepted the offer of a lower card of $\$ 40$ from computer sellers, the acceptance rates dropped significantly (to $45 \%$ ) when the offer came from a human seller who could communicate directly with the buyer. The communication made the buyer cynical and prevented him from maximizing his expected 
probability by accepting the offer when the lower card was worth $\$ 40$. As evidence of their cynicism, buyers wrote messages such as, "I think you're lying," and "Yea right, why should I believe you?" In the aggregate, cynicism worked against buyers. Moreover, the sellers strongly believed that communicating with buyers would help them close the deal (Ert, Creary, \& Bazerman, 2011), but they were wrong: cynicism turned out to be the main outcome of the communication.

In the hidden card game, potential buyers cynically assumed that they would be harmed by the seller's self-interested motives (Lewicki, McAllister, \& Bies, 1998). This phenomenon relates to work on trust, particularly the beliefs that trust inspires (Andersson, 1996), defined as “confident, positive expectations regarding another's conduct" (Lewicki, McAllister, \& Bies, 1998) or "the probability that one party attaches to cooperative behavior by other parties" (Hwang \& Burgers, 1997). By contrast, a cynical person will have more negative expectations of others and view them as egocentrically biased.

A cynical belief that another person is motivated primarily by self-interest can trump evidence to the contrary. Critcher and Dunning (2010) found evidence that people tend to scrutinize and construe even selfless behavior in self-interested terms. On the flip side, we fail to dissect selfish behavior in the same manner by searching for selfless motivations. This results in an asymmetry: beliefs about selfless motivations resist evidence to the contrary, and beliefs about selfish motivations go unquestioned (Fetchenhauer \& Dunning, 2010). Why the discrepancy? When people resist trusting others, they usually lack opportunities to learn whether their trust would have reaped rewards. By contrast, when we offer our trust, the most salient learning occurs when the other party proves to be untrustworthy. Hence, this feedback asymmetry breeds growing cynicism. 
In some intriguing new research of particular interest for readers of this volume, Barsade, Ramarajan, and Goncolo (2011) found support for a "cynical attribution error" in one of the few existing field experiments about attributions in the workplace. In the nationwide sample, people showed a systematic and widespread bias in their attributions about other employees' actions. They were more likely to attribute other employees' negative acts to those individuals themselves, while attributing others' positive acts to external or situational causes. This was not the case when it came to interpretations about their own actions. People made internal attributions about their own positive actions, while attributing their own negative actions to situational forces.

This work highlights one element that has not been fully considered by managers: the important role that emotions play, not just as organizational outcomes of interest, but also as causes of attributions about events and incidents in the workplace. How people feel about others' behaviors and actions may be instrumental in the asymmetric and different understandings of and reactions to others. For example, the positive emotions induced by others' positive behaviors can actually contribute to a harmful discounting of those positive behaviors. Such effects can in turn reduce organizational citizenship behaviors and allow conflict and organizational cultures of cynicism to fester.

Next, we explore our negative views about others and the potential consequences of such cynicism for negotiations, including both the direct effects (goals and standards) and indirect effects (assumptions and perspectives about the nature of others) that become the lens through which we view negotiation interactions. 


\section{Cynical Errors in Negotiation}

As in other contexts that involve competition and conflict, being too cynical can be costly in negotiation. Perhaps one of the most compelling historical examples is the American reaction to the Russian proposal for disarmament during the Cold War (Ross \& Stillinger, 1991; Ross, 1995). American politicians devalued the proposal simply because it was offered by the other party, with suboptimal outcomes for both sides. While Ross and Stillinger showed the effect in controlled laboratory studies, former United States Congressman Floyd Spence (R-South Carolina) captured this type of cynicism when he noted: "I have had a philosophy for some time in regard to SALT [the proposed agreement], and it goes like this: the Russians will not accept a SALT treaty that is not in their best interest, and it seems to me that if it is their best interests, it can't be in our best interest" (Ross \& Stillinger, 1991).

In many cases, features inherent to the context of negotiation-including power asymmetries, uncertainty, disagreement on key terms and definitions, and egocentric reasoningcontribute to differences in construals or interpretations (Hsee, 1995; Wade-Benzoni, Tenbrunsel, \& Bazerman, 1996). Such conditions are ripe for mutual distrust, which in turn affects expectations and actual behavior. For example, Tenbrunsel (1999) discusses the prevalence of distrust and negative expectations of "the other side" in environmental-economic disputes (Hollis, 1996).

When negotiators do not trust each other, they rely on distributive and competitive strategies, and they focus on getting concessions rather than on problem-solving, resulting in reduced information exchange (Kimmel, Pruitt, Magenau, Konar-Goldband, \& Carnevale, 1980) and information concealment (Terhune, 1970). Such negotiators also forgo the many benefits of trust, such as greater coordination (Bradach \& Eccles, 1989), cooperation (Ross \& Wieland, 1996), and revelation of more accurate information (Zand, 1972). The evidence of the impact of these 
changes on the joint outcomes of the negotiation is somewhat mixed, but withholding information is likely to lead to reciprocal perceptions of the other party as untrusting (Butler, 1991; Dore, 1987), leading to further mistrust and withholding.

These negative expectations of others may be captured by "social cynicism" (Li, Zhou, \& Leung, 2010), which also harms outcomes in negotiation. By contributing to reduced satisfaction in individual relationships (Leung \& Bond, 2004), reduced use of collaborative and compromising styles in conflict resolution (Bond, Leung, Au, Tong, \& Chemonges-Nielson, 2004), increased use of pressure and coercion (Fu, Kennedy, Tata, Yukl, Bond, \& Peng, 2004), and decreased interpersonal trust and cognitive flexibility (Singelis, Hubbard, Her, \& An, 2003), cynicism regarding others' motivations may become a self-fulfilling prophecy that leaves both sides worse off than would otherwise be the case.

Kruger and Gilovich (1999) have demonstrated a basic "naïve cynicism," in which people in a number of different domains cynically believed that others would give biased estimates when assessing their contribution to joint outcomes, despite believing themselves to be immune to such bias and independent of whether or not the allocations actually were biased. This naïve cynicism likely has a host of consequences for negotiations, ranging from relationship discord to bargaining impasse. By consistently expecting others, but not themselves, to have biased motivations, people become "self-interest theorists" (Miller \& Ratner, 1998) whose cynical expectations are not even met by those who do act in a self-serving manner. This may be in part due to the norm of selfinterest (Miller, 1999), such that the assumption that self-interest is a strong determinant of behavior leads people to act and speak as if it were actually a primary basis of behavior. Our cynicism may have roots in early childhood, as young children have been shown to assume that 
incorrect statements aligned with speakers' self-interests arise from the intent to deceive (Mills \& Keil, 2004).

These cynical assumptions extend beyond the estimates in contribution. For example, Krueger and Gilovich (1998) also have found that people tend to intuitively expect others to overestimate their own abilities. In addition, the tendency to favor oneself when interpreting uncertain information may cause others to believe that we are intentionally misleading them or misrepresenting facts (Tenbrunsel, 1999; Tsay \& Bazerman, 2009). If our assumptions of others' biases exceed their actual biases, conflict, blame, and distrust will naturally follow. Given such effects, the equilibrium converges toward an excess of cynicism (Kramer, 1998).

Similarly, "naïve" or lay cynicism can crop up in perceptions of negotiation processes. When O'Connor and Adams (1999) asked novice negotiators to list all the actions they believe contribute to successful negotiations, they agreed that such interactions are necessarily competitive because parties hold incompatible interests. Like our natural inclination to be cynical about others' motivated biases, we expect "settlement to be difficult, intransigence to be likely, and outside assistance to be necessary" in negotiation (Tenbrunsel, 1995). Uncertainty and power dynamics can exacerbate these tendencies. Tenbrunsel (1995) found that when a negotiator was uncertain about the information possessed by an opponent, the opponent was more likely to expect that negotiator to misrepresent their own information. In other research, Tenbrunsel and Messick

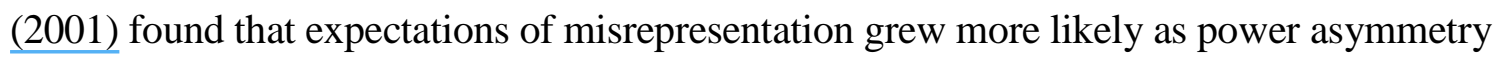
increased.

Cynicism may also arise with the induction of certain mindsets (Oza, Srivastava, \& Koukova, 2010). The minimal ways in which induction of suspicion can be achieved suggest the ease with which people may become more vigilant towards other parties during a negotiation. For 
example, Oza et al. (2010) activated knowledge about the potential influence of persuasion in bargaining tasks through a variety of simple methods, such as presenting readings about persuasion tactics or describing the other party as a sales expert. While awareness of the influence of psychological factors such as opponent response time, emotions, and provision of reference prices can help people cope with persuasion attempts and tactics, it may leave us overly cynical about our counterparts.

In addition, cues can activate persuasion knowledge and a suspicious mindset (Cappella \& Jamieson, 1997) that affect negotiators' satisfaction with bargaining processes and contribute to negative outcomes. Both objective outcomes and psychological factors influence how satisfied people are with bargaining outcomes (Neale \& Bazerman, 1991; Curhan, Elfenbein, \& Xu, 2006), and satisfaction influences the likelihood and quality of future interactions, as well as commitment to the negotiated agreement. For example, how interactions are framed—whether as "social dilemmas" or "ultimatum games" — can have a dramatic impact on decisions and cooperation (Larrick \& Blount, 1997). Even surveillance systems meant to set standards and increase cooperation can change the focus of a decision frame from ethics to economics, and from joint outcomes to individual outcomes (Tenbrunsel \& Messick, 1998). Certain contexts may be associated with warranted cynicism, which play a role in how people enact a socially constructed environment and subjectively interpret others' actions and decisions.

For example, framing may also affect how similar information is perceived when the source of that information differs. Negative intentions might be attributed to an opponent negotiator, as compared to a more neutral third-party (Blount \& Larrick, 2000), as one focuses more on the cynical aspects of such interpersonal relationships. Once induced, a suspicious mindset can increase counterarguments, exacerbate self-oriented biases (Blount \& Larrick, 2000), 
and result in more guarded communication, with detrimental effects for the quality of stable longterm relationships (Larson, 1992). Well-intentioned interactions may be perceived as influence tactics, leading to more opportunism, short-sighted strategies (Hwang \& Burgers, 1997), and suboptimal outcomes.

Beyond cynicism at the individual and dyadic levels of negotiation, groups of negotiators are also inclined to focus on negative aspects of others. Naquin and Kurtzberg (2009) find that due to the negativity bias (our tendency to give more weight to the negative aspects of something under evaluation) and the discontinuity effect (the tendency to interact more competitively with groups than with individuals), we focus most on the least trustworthy individual within a team when evaluating team-level trust. While average ratings of trust across individual members are higher than that of the least trustworthy member, ratings of collective team-level trust are similar to those of the least trustworthy member. The least trustworthy group member's rating is most predictive of impasse rates in distributive negotiations and joint gains in integrative negotiations.

Finally, some researchers distinguish cynicism from distrust by noting that cynicism includes not only belief (or, in the case of mistrust, a lack of belief) but also the affective component of disillusionment (Andersson, 1996; Andersson \& Bateman, 1997). While both distrust and cynicism may be disentangled into global versus situational components, this line of work suggests that cynicism is broader in nature than distrust, as it encompasses not only expectations but also negative feelings toward people, groups, or objects.

This hints at implications for the combined effects of distrust and emotions on negotiation strategies. Recent research has found that emotions can affect many factors of negotiation performance and outcomes, including bargaining tactics (Carnevale \& Isen, 1986), concessions (Sinaceur \& Tiedens, 2006), and individual and joint gains (Allred, Mallozzi, Matsui, \& Raia, 
1997). In one line of work (Lerner\& Keltner, 2000), anger and compassion were found to have different influences on negotiation behavior and goals via trust. Distrust increases the perceived importance of competitive goals but is negatively and weakly associated with cooperative goals (Liu \& Wang, 2010), thus reducing the likelihood of maximizing joint gains through open communication. It would be worthwhile to further investigate the affective and cognitive aspects of cynicism. There remains a relatively broad range of ways in which scholars have defined cynicism, although here we have restricted ourselves to a more narrow definition with regards to cynical errors. Greater precision in defining cynicism as a concept may be well balanced with continuing dialogues with the literatures on trust and affect.

\section{Cynical Errors in Auctions and Economic Games}

When do people trust too much or too little relative to what a rational economic analysis would suggest? Research in behavior in economic games can help us identify the boundary between too much and too little trust by defining an optimal level for an individual to trust based on the average level of trust and trustworthiness in a group. The "trust game" can be used to diagnose an individual's attitudes regarding trust relative to a group standard (Berg, Dickhaut, \& McCabe, 1995). The structure is as follows:

One individual is assigned to be the sender, who decides how much money out of an initial endowment (as set by the experimenter) to send to another individual (the receiver). The experimenter multiplies the amount the sender gives to the receiver (typically by three, based on Berg et al., 1995) and this new amount is in the receiver's hands. The receiver subsequently decides how much of the money received to send back to the sender. Sender and receiver roles are randomly assigned in the trust game, and full rules of the game- 
including the initial endowment, the size of the multiplier (which can be increased to entice the sender to send more to increase the pool of money), and the sequence in which decisions will be made - are disclosed to both parties at the start of the game. The structure of the game allows us to experimentally detect trust (through the amount the sender entrusts with the receiver) and trustworthiness (through the amount the receiver sends back to the sender in reciprocation).

Neoclassical economic theory adopts the perspective of a self-interested utility-maximizing actor. From this perspective, in a game where roles are anonymous and interaction is limited to a single round, a rational self-interested sender should anticipate that a rational self-interested receiver will not send back any money; therefore, the sender should send nothing. Yet trust and trustworthiness are consistently present in such games, even in this stripped-down, single-shot, anonymous version. Senders on average will give receivers more than half of their initial endowments to be tripled by the experimenter. Receivers on average reciprocate by giving more than a third of the amount they receive to senders; hence, senders are typically rewarded for their initial trust (see Camerer, 2003, for a detailed review).

Thus, the trust game can be used to identify the boundary between a naïve error and a cynical error. In this particular game, a sender makes a naïve error when she fails to take into account the self-interested motives of her receiver. She may willingly entrust her receiver with the entire initial endowment so as to maximize the total amount the receiver has to split between the two of them after the multiplier is applied. If she meets a fully self-interested receiver who capitalizes on her naiveté by returning nothing and keeping the entire pool of funds, she has made the ultimate naïve error. On the opposite end of the spectrum, a sender makes a cynical error when 
she over-anticipates the self-interested motives of her receiver. With these paranoid suspicions, she will send very low amounts, thus diminishing the potential pool of money that she and her receiver could share.

Fetchenhauer and Dunning (2009) use the trust game to investigate whether or not people trust too much or too little; they exploit the trust game's design to compare counterfactual outcomes (i.e., what would have happened had everyone played with a participant at the group median levels of trust and trustworthiness) as a benchmark against actual performance of senders and receivers. They found evidence of both too much trust (given participants' expectations of the trustworthiness of others) and too little trust (given their tolerance for risk). Senders hugely underestimated the trustworthiness of receivers and gave up earnings they would have received had they been less cynical. Senders also seemed to exhibit too much trust based on their expressed tolerance of risk (Fetchenhauer \& Dunning, 2009).

From a sender's perspective, a one-shot trust game can be considered to be equivalent to a risky bet (with risk calculated as the anticipated trustworthiness of any average receiver). Prior work has established that a trust decision entails an additional risk premium added to the preexisting risk tolerance of receivers - apparently to alleviate any possible trust betrayal (the pain of unreciprocated trust), which seems to hurt more than losing a statistically equivalent risky bet (Bohnet \& Zeckhauser, 2004). In Fetchenhauer and Dunning's experiments (2009), despite participant cynicism regarding the untrustworthy nature of receivers, senders were more likely to gamble their money by giving it to a receiver they believed to be untrustworthy than by entering a lottery with higher odds than those they believed they would receive from the rare trustworthy receiver. Thus, from a risk perspective, despite harboring cynical views that most people are 
untrustworthy and despite demanding a premium for the possible pain of trust betrayal, people still appear to trust more than their risk appetites predict.

The trust game creates a controlled environment in which individual levers of trust can be identified. Across studies, less than ten percent of senders give receivers nothing, and less than a quarter of receivers give senders nothing back (Berg et al., 1995; Croson \& Buchan, 1999;

Johansson-Stenman et al, 2005). These effects are similar for trust games conducted in the United States, China, Japan, and Korea (Croson \& Buchan, 1999). Furthermore, gender has no significant effect on senders' trust behavior; however, female receivers do tend to reciprocate significantly more of their wealth (hence demonstrating more trustworthy behavior) than males do in all observed contexts (Croson \& Buchan, 1999).

What happens as the stakes of the game increase? One study conducted in rural Bangladeshi villages gave senders initial endowments worth almost $5 \%$ of the gross national income per capita (Johansson-Stenman, Mahmud, \& Martinsson, 2005). Senders on average still gave more than a third of their initial endowments to anonymous receivers, and receivers on average gave more than a third of what they received back to senders. Even with such meaningful, life-changing amounts of money at stake, just three percent of senders sent nothing to receivers, and nine percent of receivers sent nothing back to senders. Trust persists even in high-stakes environments.

\section{FINDING THE RIGHT BALANCE}

There is no easy answer as to whether being trusting or cynical is the best strategy. It is clear, however, that you would be wise to think carefully about the decisions and motives of the other party so that you can understand what the problem looks like from his or her perspective. 
This may help you identify when reasons to trust exist and when you have reason to be cynical. In this section, we propose several strategies as solutions to both naïve and cynical errors.

\section{Learning and Understanding through Examples}

Many researchers have tried to show that errors of naiveté are not easily eliminated with experience. The winner's curse and the failure to appropriately adjust behavior in light of others' decisions have been shown to persist even with many trials and with very strong feedback (Grosskopf, Bereby-Meyer, \& Bazerman, 2007). More promising is research suggesting that the costs of these naïve errors may be ameliorated by comparing and contrasting choices within and across parallel related problems, which leads to a better understanding of the Acquiring a Company problem (Idson, Chugh, Bereby-Meyer, Moran, Grosskopf, \& Bazerman, 2004). This research is consistent with earlier work on analogical learning, which suggested that principles were better abstracted and utilized in new situations when analogies were drawn from the comparison of several examples (Loewenstein, Thompson, \& Gentner, 1999).

\section{Perspective Taking}

Neale and Bazerman (1983) found that individuals who had a greater tendency to think about the perspectives of others were more successful in laboratory negotiations. This focus on the perspective of the other party allowed better predictions of opponents' goals, expectations, and reservation points. While taking the perspective of the other party is important, most individuals lack sufficient perspective-taking ability (Bazerman \& Neale, 1983; Bernstein \& Davis, 1982; Davis, 1981). Overall, negotiators tend to act as if their opponents were inactive parties in the negotiation and they systematically ignore valuable information that is available. Bazerman and Neale (1982) suggest that training mechanisms should be developed to increase the perspective-taking ability of negotiators. This prescription is consistent with the literature on 
negotiator role reversal, which suggests that having each bargainer verbalize the other side's viewpoint increases the likelihood of a negotiated resolution (Pruitt, 1981). Similarly, encouraging negotiators to take their opponents' perspective should be a central focus of mediators.

In competitive contexts, a healthy skepticism that treats counterparts as having several possible motives, both benevolent and malevolent (Fein, 1996; Sinaceur, 2010), may enhance information search and integrative agreements. Additionally, an awareness of others' perspectives may also help counter cynical errors. Tenbrunsel (1999) suggests that focusing on optimal solutions in which power comes from coordination and creative solutions rather than control and enforcement will help encourage integrative outcomes, cooperative behavior, and greater trust.

One caveat to perspective-taking should be noted. Berks, Carpenter, and Verhoogen (2003) investigated the impact of participants playing both roles in the trust game with different partners. One prediction is that forcing people to take both perspectives will increase levels of trust and trustworthiness. The authors found the opposite result: participants who played both roles actually exhibited less trust and reciprocal trustworthiness, though only when the two-role structure of the game was made clear before rounds were played. This result appears to suggest that priming a rational game-strategic mindset by having participants consider their potential income in two rounds with different partners can increase rather than decrease self-interested motives.

\section{The Role of Communication, Information, and Relationships}

Economic analysis shows that it is quite possible for sophisticated, fully rational negotiators to reach an impasse despite having a sizeable zone of possible agreement within both of their reservation values-i.e., less than the most the buyer will pay and more than the least the seller will accept (Myerson \& Satterthwaite, 1983). The seller may try to beat her reservation price if she thinks the probability of the buyer paying more is reasonably high. Similarly, the 
buyer may try to shave more off his reservation price if he thinks there is a good chance of getting such a concession from the seller. Due to each side's strategic thinking about how to maximize their respective payoffs, it is quite possible for rational parties to reach an impasse despite having a zone of possible agreement.

When communication between parties is strong, however, there are several ways they can avoid the impasse that such strategic concerns foster (Bazerman, Gibbons, Thompson, \& Valley, 1998). Because negotiators care about their reputation and the outcomes of others, they may relax their strategic concerns and improve the quality of the information exchange. Negotiators correctly believe that acting with integrity increases the likelihood that the other side will respond with integrity; as such, they may regard open and honest communication as good investments. Finally, negotiators tend to view impasse as a negative event. Many are willing to forego some expected financial benefit in order to reach agreement.

Parties may be more trusting than we might expect from a full rational self-interest perspective, and strong communication plays a critical role in fostering this trust. When different interests are represented by multiple people, one way to establish a foundation for high-quality communication is to clearly target specific negotiators, thus allowing repeated exposure to the same individuals (Berg, Dickhaut, \& McCabe, 1995), which would foster a climate of trust, greater certainty, and greater likelihood of a shared understanding of the negotiation (Tenbrunsel, 1999). A better shared framework helps parties avoid framing a negotiation as a dispute or zerosum game, therefore increasing trust (Das \& Teng, 1998).

Similarly, Kruger and Gilovich (1999) found that a cooperative, in-group orientation can lessen the assumption that others are motivationally biased. This was also found in those who have satisfying pre-existing relationships, such as spouses. On the other hand, power differences and a 
focus on power-based resolution are likely to help signal more myopic interests (Tenbrunsel, 1999). Thus, one possible way to help ameliorate our derogatory assumptions about others is to take advantage of the potentially bidirectional influence between the quality of the relationship and the level of naïve cynicism used to evaluate others.

Both individual motivations and the rules of the negotiation can also impact the effects of cynicism. Negotiators' social motives and punitive capabilities both affect trust, behavior, and joint outcomes. Collaboratively motivated negotiators communicate more openly and exhibit greater trust for other parties than do those with a competitive orientation, resulting in solutions with mutual benefits (Beersma \& De Dreu, 1999; Weingart, Bennett, \& Brett, 1993). However, those with cooperative motives are more likely to develop trust, communicate openly, share information, and achieve better joint outcomes only when the structure of the negotiation allows trust to develop (De Dreu, Giebels, \& Van de Vliert, 1998).

Finally, in our electronically connected economy, there are many ways to establish a reputation without necessarily relying on intuition about someone's trustworthiness. For instance, the actively used reference system on CouchSurfing.org facilitates trust by allowing members to vouch for the safety and goodwill of other members. When approaching new counterparts, it would be wise to consider means of communication—both in person and online - that can improve trust and reduce cynicism to create greater value for society at large. 


\section{Discussion}

Some of us err too much toward trust; others too much toward cynicism. To determine your own predisposition, consider whether you trust in the absence of information and whether you distrust despite positive information about another person's potential trustworthiness. If you trust in the former scenario, you may expose yourself to unnecessary risks if you encounter untrustworthy counterparts. If you distrust in the latter scenario, your stubborn cynicism may lead you to suboptimal outcomes in interactions requiring trust. Through our examples and review of both naïve and cynical errors, we hope to encourage more awareness of the strategic behavior of others, without destroying opportunities for trust building.

Whether as a practitioner, scholar, or teacher, education plays an important role in finding the right balance between naiveté and cynicism in competitive contexts. While multiple simulations exist to demonstrate naïve behavior, such as the Acquiring a Company problem (Bazerman \& Moore, 2008), we still need to develop better tools to demonstrate the downsides of cynicism. This can be a daunting charge, considering that we may be more aware of and more cautioned against the risks in being too naïve, while we are less aware of the ways that incidental situational cues and our emotions, intuitions, and even education can contribute to cynical errors. For example, some of the prescriptions for countering naïve errors may well push us towards cynicism. It would also be prudent to consider the potential limitations of any prescriptions for ameliorating naïve and cynical errors, such as how and to what degree they may influence experienced negotiators, and how contingencies such as culture might affect their effectiveness, given the difficulties in translating between some of the existing negotiations research and organizational life (Staw, 2010). 
While we hope that we have provided useful examples of where people err by being too naïve and where they err by being too cynical, we hope that future research will develop frameworks to help people see when each of these opposing errors is most likely to occur. In some cases, the mere presence of another person on the other side of a transaction seems to lead people to cease to use economic logic. Our myopic focus on ourselves and our failures to consider others and the situation itself can also lead us to both naïve and cynical errors. We believe that the psychological literature provides hints about when and why such cases occur. The development of an integrated framework to account for, anticipate, and buffer against the spectrum of naïve and cynical errors is a task that remains for future research. 


\section{References}

Akerlof, G. 1970. The market for "Lemons": Quality uncertainty and the market mechanism. Quarterly Journal of Economics, 89: 488-500.

Allred, K. G., Mallozzi, J., Matsui, F., \& Raia, C. P. 1997. The influence of anger and compassion on negotiation performance. Organizational Behavior and Human Decision Processes, 70: 175-187.

Andersson, L. M. 1996. Employee cynicism: An examination using a contract violation. framework. Human Relations, 49 (11): 1395-418.

Andersson, L. M., \&Bateman, T. 1997. Cynicism in the workplace: causes and consequences, Journal of Organizational Behavior, 18: 449-469.

Babcock, L., \& Loewenstein, G. 1997. Explaining bargaining impasse: the role of self-serving biases. Journal of Economic Perspectives, 11: 109-126.

Ball, S.B., Bazerman, M.H., \& Carroll, J.S. 1991. An evaluation of learning in the bilateral winner's curse. Organizational Behavior and Human Decision Processes, 48: 1-22.

Barsade, S., Ramarajan, L., \& Goncolo, J. 2011. Cynicism or benevolence?: The role of positive and negative acts on work place attributions. Working paper, The Wharton School, University of Pennsylvania.

Bazerman, M. H., \& Chugh, D. 2006. Bounded awareness: focusing failures in negotiation. In L. Thompson, L. (Ed.), Negotiation Theory and Research (pp. 7-26). New York: Psychology Press.

Bazerman, M.H., Gibbons, R.S., Thompson, L.L., \& Valley, K.L. 1998. Can negotiators outperform game theory? In J.H. Halpern \& R.N. Stern (Eds.), Debating Rationality: Nonrational Aspects of Organizational Decision Making. ILR Press. 
Bazerman, M.H., \& Moore, D. 2008. Judgment in Managerial Decision Making. Hoboken, NJ: Wiley.

Bazerman, M. H., \& Neale, M. A. 1982. Improving negotiation effectiveness under final offer arbitration: The role of selection and training. Journal of Applied Psychology, 67(5): 543-548.

Beersma, B., \& De Dreu, C. K. W. 1999. Negotiation processes and outcomes in pro-socially and egoistically motivated groups. International Journal of Conflict Management, 10: $385-402$.

Bereby-Meyer, Y., \& Grosskopf, B. 2008. Overcoming the winner's curse: an adaptive learning perspective. Journal of Behavioral Decision Making, 21: 15-27

Berg, J., Dickhaut, J., \& McCabe, K. 1995. Trust, reciprocity, and social history. Games and Economic Behavior, 10: 122-142.

Bernstein, W. M., \& Davis, M. H. 1982. Perspective-taking, self-consciousness, and accuracy in person perception. Basic and Applied Social Psychology, 3: 1-19.

Blount, S., \& Larrick, R. 2000. Framing the game: Examining frame choice in bargaining. Organizational Behavior and Human Decision Processes, 81: 43-71.

Bohnet, I., \& Zeckhauser, R.2004. Trust, risk and betrayal. Journal of Economic Behavior \& Organization, 55: 467-484.

Bond, M. H., Leung, K., Au, A., Tong, K-Kit, \& Chemonges-Nielson, Z. 2004. Combining social axioms with values in predicting social behaviours. European Journal of Personality, 18: 177-191.

Bradach, J., \& Eccles, R. 1989. Price, authority, and trust: From ideal types to plural forms. Annual Review of Sociology, 15: 97-118. 
Butler, J. K. 1999. Trust expectations, information sharing, climate of trust andnegotiation: effectiveness and efficiency. Group and Organization Management, 24: 217-238.

Camerer, C. 2003. Behavioral Game Theory: Experiments in Strategic Interaction.Princeton University Press.

Cappella, J. N., \& Jamieson, K. H. 1997. Spiral of Cynicism. New York: Oxford University Press.

Carnevale, P. J. D., \& Isen, A. M. 1986. The influence of positive affect and visual access on the discovery of integrative solutions in bilateral negotiation. Organizational Behavior and Human Decision Processes, 37(1): 1-13.

Carroll, J. S., Bazerman, M. H., \& Maury, R. 1988. Negotiator cognitions: A descriptive approach to negotiators' understanding of their opponents. Organizational Behavior \& Human Decision Processes, 41(3): 352-370.

Cesarini, D., Dawes, C., Fowler, J., Johannesson, M., Lichtenstein, L., \& Wallace, B. 2008. Heritability of cooperative behavior in the trust game. Proceedings of the National Academy of Sciences, 105 (10): 3721-3726.

Critcher, C. R., \& Dunning, D. 2010. No good deed goes unquestioned: Cynical reconstruals maintain belief in the power of self-interest. Working paper.

Croson, R., \& Buchan, B. 1999. Gender and culture: International experimental evidence from trust games. American Economic Review: Papers and Proceedings, 89 (2): 386-391.

Curhan, J. R., Elfenbein, H. A., \& Xu, H. 2006. What do people value when they negotiate? Mapping the domain of subjective value in negotiation. Journal of Personality and Social Psychology, 91: 493-512. 
De Dreu, C. K. W., Giebels, E., \& Van de Vliert, E. 1998. Social motives and trust in integrative negotiation: Disruptive effects of punitive capability. Journal of Applied Psychology, 83: 408-422.

Dean, J., Brandes, P., \& Dharwadkar, R. 1998. Organizational cynicism. Academy of Management Review, 23: 341-352.

Deutsch, M. 1960. The effect of motivational orientation upon trust and suspicion. HumanRelations, 13: 123-139.

Dore, R. 1987. Taking Japan Seriously: A Confucian Perspective on Leading Economic Issues. Stanford, CA: Stanford University Press.

Dyer, D., Kagel, J., \& Levin, D. 1989. A comparison of naive and experienced bidders in common value offer auctions: A laboratory analysis. Economic Journal, Royal Economic Society, 99(394): 108-115.

Ert, E., \& Bazerman, M. 'If you want to sell, sell. don't talk': When talking to buyers increase skepticism. IACM 23rd Annual Conference Paper. Available at SSRN: http://ssrn.com/abstract=1612493.

Graham, J. R. 1993. MMPI-2: Assessing Personality and Psychopathology (2nd ed.). New York: Oxford University Press.

Fein, S. 1996. Effects of suspicion on attributional thinking and the correspondence bias. Journal of Personality and Social Psychology, 70: 1164-1184.

Fetchenhauer, D., \& Dunning, D. 2009. Do people trust too much or too little? Journal of Economic Psychology, 30: 263-276. 
Fetchenhauer, D., \& Dunning, D. 2010. Why so cynical? Asymmetric feedback underlies misguided skepticism in the trustworthiness of others. Psychological Science, 21: 189193.

Frank, R.H., Gilovich, T., \& Regan, D.T. 1993. Does studying economics inhibit cooperation? Journal of Economic Perspectives, 7: 159 - 171.

Friestad, M., \& Wright, P. 1994. The persuasion knowledge model: How people cope with persuasion attempts. Journal of Consumer Research, 21: 1-31.

Fu, P. P., Kennedy, J., Tata, J., Yukl, G., Bond, M. H., \& Peng, T. K. 2004. The impact of societal cultural values and individual social beliefs on the perceived effectiveness of managerial influence strategies: A meso approach. Journal of International Business Studies, 38: 284-304.

Grosskopf, B., Bereby-Meyer Y., \& Bazerman, M. 2007. The robustness of the winner's curse phenomenon. Theory and Decision: 389-418

Hollis, M. 1996. Debate rages over environmental bill. The Ledger: Bl.

Hwang, P., \& Burgers, W. 1997. Properties of trust: An analytical view. Organizational Behavior and Human Decision Processes, 69(1): 67-73.

Hsee, C. K. 1995. Elastic justification: How tempting but task-irrelevant factors influence decisions. Organizational Behavioral and Human Decision Process, 62: 330-337.

Idson, L. C., Chugh, D., Bereby-Meyer, Y., Moran, S., Grosskopf, B., \& Bazerman, M. H. 2004. Overcoming focusing failures in competitive environments. Journal of Behavioral Decision Making, 17: 159-172.

Johansson-Stenman, O., Mahmud, M., \& Martinsson, P. 2005. Does stake size matter in trust games? Economics Letters, 88: 365-369. 
Kimmel, M., Pruitt, D., Magenau, J., Konar-Goldband, E., \& Carnevale, P. 1980. Effects of trust, aspiration, and gender on negotiation tactics. Journal of Personality and Social Psychology, 38(1): 9-22.

Kramer, R. 1998. Paranoid cognition in social systems. Personality and Social Psychology Review, 2: $251-275$

Kramer, R. M., \&Lewicki, R. J. 2010. Repairing and enhancing trust: Approaches to reducing organizational trust deficits. Academy of Management Annals, 4: 245-277.

Kruger, J., \& Gilovich, T. 1999. "Naive cynicism" in everyday theories of responsibility assessment: On biased perceptions of bias. Journal of Personality and Social Psychology, 76: 743-753.

Larrick, R. P., \& Blount, S. 1997. The claiming effect: Why players are more generous in social dilemmas than in ultimatum games. Journal of Personality and Social Psychology, 72:810-825.

Larson, A. 1992. Network dyads in entrepreneurial settings: A study of the governance of exchange relationships. Administrative Science Quarterly, 37:76-100.

Legrenzi, P., Girotto, V., \&Johnson-Laird. 1993. Focusing in reasoning and decision making. Cognition, 49(1-2): 37-66.

Lerner, J.S., \& Keltner, D. 2000. Beyond valence: Toward a model of emotion-specific influences on judgment and choice. Cognition and Emotion, 14: 473-493.

Leung, K., \& Bond, M. H. 2004. Social axioms: A model for social beliefs in multi-cultural perspective. In M. P. Zanna (Ed.), Advances in Experimental Social Psychology (Vol. 36, pp. 119-197). San Diego, CA: Elsevier Academic Press. 
Leung, K., Tong, K. K., \& Ho, S. S. Y. 2004. Effects of interactional justice on egocentric bias in resource allocation decisions. Journal of Applied Psychology, 89: 405-415.

Lewicki, R. J., McAllister, D. J., \& Bies, R. J. 1998. Trust and distrust: New relationships and realities. Academy of Management Review, 23: 438-458.

Li, F., Zhou, F., \&Leung, K. 2010. Expecting the worst: Moderating effects of social cynicism on the relationships between relationship conflict and negative affective reactions. Journal of Business and Psychology: 1-7.

Liu, M., \& Wang, C. 2010. Explaining the influence of anger and compassion on negotiators' interaction goals: An assessment of trust and distrust as two distinct mediators. Communication Research, 37: 443-472.

Loewenstein, J., Thompson, L., \& Gentner, D. 1999. Analogical encoding facilitates knowledge transfer in negotiation. Psychonomic Bulletin \& Review, 6(4): 586-597.

Mayer, R. C., Davis, J. H., \& Schoorman, F. D. 1995. An integration model of organizational trust. Academy of Management Review, 20: 709-734.

Miller, D. T. 1999. The norm of self-interest. American Psychologist, 54: 1-8.

Miller, D.T., \& Ratner, R.K. 1998. The disparity between the actual and assumed power of selfinterest. Journal of Personality and Social Psychology, 74: 53-62.

Mills, C. M., \& Keil, F. C. 2005. The development of cynicism. Psychological Science, 16(5): 385-390.

Mirvis, P., \&Kanter, D. 1991. Beyond demography: A psychographic profile of the workforce. Human Resource Management, 30(1): 45-68.

Mirvis, P., \&Kanter, D. 1989. Combating cynicism in the workplace. National Productivity Review, 8(4): 377-394. 
Moore, D. A. 2004. The unexpected benefits of final deadlines in negotiation. Journal of Experimental Social Psychology, 40(1): 121-127.

Myerson, R., \& Satterthwaite, M. 1983. Efficient mechanisms for bilateral trading. Journal of Economic Theory, 29: 265-281.

Naquin, C., \& Kurtzberg, T. 2009. Team negotiation and perceptions of trustworthiness: The whole versus the sum of the parts. Group Dynamics: Theory, Research, and Practice, 13(2): 133-150.

Neale, M. A., \& Bazerman, M. H. 1991. Cognition and Rationality in Negotiation. New York: Free Press.

Neale, M. A., \& Bazerman, M. H. 1983. The role of perspective-taking ability in negotiating under different forms of arbitration. Industrial and Labor Relations Review, 36(3): 378388.

O’Connell, B. J., Holzman, H. H., \& Armandi, B. R. 1986). Police cynicism and the modes of adaptation. Journal of Police Science and Administration, 14: 307-313.

O'Connor, K. M., \& Adams, A. A. 1999. What novices think about negotiation: A content analysis of scripts. Negotiation Journal, 15: 135-147.

Pope, K. S., Butcher, J. N., \& Seelen, J. 1993. The MMPI, MMPI-2 \& MMPI-A in court. Washington, DC: American Psychological Association.

Oza, S., Srivastava, J., \& Koukova, N. 2010. How suspicion mitigates the effect of influence tactics. Organizational Behavior and Human Decision Processes, 112(1): 1-10.

Pruitt, D. 1981. Negotiation Behavior. New York: Academic Press.

Reichers, A. E., Wanous, J. P., \& Austin, J. T. 1997. Understanding and managing cynicism about organizational change. Academy of Management Executive, 11: 48-59. 
Ross, L. 1995. Reactive devaluation in negotiation and conflict resolution. In K. Arrow, R. Mnookin, L. Ross, A. Tversky, \& R. Wilson (Eds.), Barriers to the Negotiated Resolution of Conflict(pp. 30-48). New York: Norton.

Ross, L., \& Stillinger, C. 1991. Barriers to conflict resolution. Negotiation Journal, 7: 389-404.

Ross, W. H. \& Wieland, C. 1996. Effects of interpersonal trust and time pressure on managerial mediation strategy in a simulated organizational dispute. Journal of Applied Psychology, 81: $228-248$.

Rubinstein, A. 2009. Fairytales of economics (in Hebrew). Kinneret.

Samuelson, W. F., \& Bazerman, M. H. 1985. The winner's curse in bilateral negotiations. In V. Smith (Ed.), Research in Experimental Economics (Vol. 3). Greenwich, CT: JAI Press.

Schkade, D.A., \& Kahneman, D. 1998. Does living in California make people happy? A focusing illusion in judgments of life satisfaction. Psychological Science, 9: 340-346.

Sermat, V. 1970. Is game behavior related to behavior in other interpersonal situations? Journalof Personality and Social Psychology, 16: 92-109.

Sinaceur, M. 2010. Suspending judgment to create value: Suspicion and trust in negotiation. Journal of Experimental Social Psychology, 46 (3): 543-550.

Sinaceur, M. \& Tiedens, L. Z. 2006. Get mad and get more than even: The benefits of anger expressions in negotiations. Journal of Experimental Social Psychology, 42: 314-322.

Singelis, T. M., Hubbard, C., Her, P., \& An, S. 2003. Convergent validation of the social axioms survey. Personality and Individual Differences, 34: 269-282.

Staw, B. 2010. The trouble with JDM: Some limitations to the influence of JDM on organizational research. Industrial and Organizational Psychology, 3: 411-416. 
Tenbrunsel, A.E. 1999. Trust as an obstacle in environmental-economic disputes. American Behavioral Scientist, 42: 1350-1367.

Tenbrunsel, A., \& Messick, D. 2001. Power asymmetries and the ethical atmosphere in negotiations. In J.M. Darley, D.M. Messick, \& T.R. Tyler (Eds.) Social Influences on Ethical Behavior in Organizations. Hillsdale: Lawrence Erlbaum.

Terhune, K.W. 1970. The effects of personality in cooperation and conflict. In E Swingle (Ed.), The Structure of Conflict (pp. 193-234). New York: Academic Press.

Thaler, R. H. 1988. The winner's curse. The Journal of Economic Perspectives, 2: 191-202.

Thompson, L., \& Loewenstein, G. 1992. Egocentric interpretations of fairness and negotiation. Organization Behavior and Human Decision Processes, 51: 176-197.

Tor, A., \& Bazerman, M. H. 2003. Focusing failures in competitive environments: Explaining decision errors in the Monty Hall game, the acquiring a company problem, and multiparty ultimatums. Journal of Behavioral Decision Making, 16(5): 353-374.

Tsay, C., \& Bazerman, M. 2009. A decision-making perspective to negotiation: A review of the past and a look into the future. Negotiation Journal, 25(4): 465-478.

Wade-Benzoni, K. A., Tenbrunsel, A. E., \& Bazerman, M. H. 1996. Egocentric interpretations of fairness in asymmetric, environmental social dilemmas: Explaining harvesting behavior and the role of communication. Organizational Behavior \& Human Decision Processes, 67(2): 111-126.

Wang, L., Malhotra, D., \& Murnighan, J. K. In press. Economics education and greed. Academy of Management Learning \& Education. 
Wanous, J. P., Reichers, A. E., \& Austin, J. T. 2000. Cynicism about organizational change: Measurement, antecedents, and correlates. Group and Organization Management, 25: $132-153$.

Weingart, L. R., Bennett, R. J., \& Brett, J. M. 1993. The impact of consideration of issues and motivational orientation on group negotiation process and outcome. Journal of Applied Psychology, 78:504-517.

Wilson, T. D., Wheatley, T., Meyers, J. M., Gilbert, D. T., \& Axsom, D. 2000. Focalism: A source of durability bias in affective forecasting. Journal of Personality and Social Psychology, 78: 821-836.

Zand, D. E. 1972. Trust and managerial problem solving. Administrative Science Quarterly, 17: 229-239. 